\title{
Soil erosion, sediment yield and sedimentation of reservoir: a review
}

\author{
S. Dutta ${ }^{1}$
}

Received: 17 June 2016/Accepted: 24 June 2016/Published online: 2 July 2016

(C) Springer International Publishing Switzerland 2016

\begin{abstract}
Sedimentation is an important parameter to assess the life of a reservoir. Seventy-eight years ago, Cook was the first to identify mathematically, the three major factors affecting soil erosion in the catchment of a reservoir. As sedimentation is dependent on sediment yield and sediment yield depends on soil erosion, it is required to predict all three parameters to estimate the life of a reservoir. Since then many researchers carried their research dealing with soil erosion, sediment yield and sedimentation in various reservoirs for its practical significance. The aim of this article is to present a comprehensive state-of-the-art review of the important investigations on soil erosion, sediment yield and sedimentation in various reservoirs highlighting the governing mathematical background of these problems. 198 references are included in this review paper.
\end{abstract}

Keywords Erosion $\cdot$ Sediment yield $\cdot$ Sedimentation Sediment delivery ratio $\cdot$ Trap efficiency $\cdot$ Storage capacity

\section{List of symbols}

$\begin{array}{ll}C^{\prime \prime} & \begin{array}{l}\text { Constant } \\ \text { Soil loss per unit area in unit time } \\ \left(\mathrm{ML}^{-2} \mathrm{~T}^{-1}\right)\end{array} \\ S & \text { Slope-steepness factor } \\ L & \text { Slope length factor } \\ P & \text { Support practice factor } \\ R & \text { Rainfall erosivity factor }\left(\mathrm{MLT}^{-4}\right) \\ K & \text { Soil erodibility factor }\left(\mathrm{L}^{-3} \mathrm{~T}^{3}\right) \\ C & \text { Cover management factor }\end{array}$

S. Dutta

subhasri_dutta@swr.iitkgp.ernet.in

1 School of Water Resources, Indian Institute of Technology Kharagpur, Kharagpur 721302, India

\begin{tabular}{|c|c|}
\hline$E I_{30}$ & Rainfall erosion index $\left(\mathrm{MLT}^{-3}\right)$ \\
\hline$K E$ & Kinetic energy of the rainfall $\left(\mathrm{MT}^{-2}\right)$ \\
\hline$I_{30}$ & $\begin{array}{l}\text { Maximum } 30 \text { min intensity of the rainfall } \\
\left(\mathrm{LT}^{-1}\right)\end{array}$ \\
\hline$I$ & Rainfall intensity $\left(\mathrm{LT}^{-1}\right)$ \\
\hline$n$ & $\begin{array}{l}\text { Total number of years over which data } \\
\text { was collected }\end{array}$ \\
\hline$j$ & Number of year up to $n$ \\
\hline$m$ & Total number of storms in a year \\
\hline$k$ & Number of individual storm up to $m$ \\
\hline$e_{r}$ & $\begin{array}{l}\text { Rainfall energy per unit depth of rainfall } \\
\text { per unit area }\left(\mathrm{ML}^{-1} \mathrm{~T}^{-2}\right)\end{array}$ \\
\hline$p_{r}$ & $\begin{array}{l}\text { Depth of rainfall for the } r^{\text {th }} \text { increment of a } \\
\text { storm hyetograph which is divided into } \tilde{m} \\
\text { parts having constant rainfall intensity (L) }\end{array}$ \\
\hline$\tilde{m}$ & $\begin{array}{l}\text { Division of storm hyetograph having } \\
\text { constant rainfall intensity } e_{r}\end{array}$ \\
\hline$i_{r}$ & $\begin{array}{l}\text { Constant intensity over the time increment } \\
\left(\mathrm{LT}^{-1}\right)\end{array}$ \\
\hline$t_{r}$ & Length of time of the $r$ th increment $(\mathrm{T})$ \\
\hline$F$ & Modified Fournier index (L) \\
\hline$p_{i}$ & Mean rainfall for month $i(\mathrm{~L})$ \\
\hline $\bar{P}$ & Mean annual rainfall depth (L) \\
\hline$d_{g}$ & Geometric mean particle size (L) \\
\hline$f_{i}$ & Mass fraction of $i$ th particle \\
\hline$d_{i}$ & Maximum diameter of particle (L) \\
\hline$d_{i-1}$ & Minimum diameter of particle $(\mathrm{L})$ \\
\hline$L S$ & Topographic factor \\
\hline$\lambda$ & Field slope length (L) \\
\hline$k^{\prime}$ & Exponent factor value \\
\hline$\theta$ & Angle of slope \\
\hline$m^{\prime \prime}$ and $n^{\prime \prime}$ & Fitted regression coefficient \\
\hline$A_{\text {crop }}$ & $\begin{array}{l}\text { Soil loss from cropped land area } \\
\left(\mathrm{ML}^{-2} \mathrm{~T}^{-1}\right)\end{array}$ \\
\hline
\end{tabular}




$\begin{array}{llll}A_{\text {fallow }} & \text { Soil loss from fallow land area } & p & \text { Peak value } \\ & \left(\mathrm{ML}^{-2} \mathrm{~T}^{-1}\right) & S V & \text { Sediment volume } \\ N D V I & \text { Normalized difference vegetation index } & \text { Catch } & \text { Catchment } \\ L_{T M} & \text { Landsat ETM } & s & \text { Sediment } \\ \alpha, \beta & \text { Two dimensionless parameters } & d & \text { Density } \\ Y & \text { Sediment yield in a given day }(\mathrm{M}) & S(p+1) & \text { Sediment at }(p+1) \text { increment } \\ Q & \text { Annual runoff volume }\left(\mathrm{L}^{3}\right) & \text { res }(p) & \text { Reservoir at increment } p \\ q_{p^{\prime}} & \text { Peak rate of runoff volume }\left(\mathrm{L}^{3} \mathrm{~T}^{-1}\right) & \text { res }(p+1) & \text { Reservoir at increment }(p+1) \\ Q_{S V} & \text { Volume of sediment yield per year } & 0 & \text { Original } \\ & \left(\mathrm{L}^{3} \mathrm{~T}^{-1}\right) & p^{\prime} & \text { Relative }\end{array}$

$A_{\text {catch }} \quad$ Catchment area $\left(\mathrm{L}^{2}\right)$

$Q_{s} \quad$ Annual sediment yield rate $\left(\mathrm{MT}^{-1}\right)$

$Q^{\prime} \quad$ Mean annual sediment yield $\left(\mathrm{L}^{3}\right)$

$D_{d} \quad$ Drainage density $\left(\mathrm{L}^{-1}\right)$

$F A \quad$ Arable land in the catchment $\left(\mathrm{L}^{2}\right)$

$F G \quad$ Grass land in the catchment $\left(\mathrm{L}^{2}\right)$

FF Forest land in the catchment $\left(\mathrm{L}^{2}\right)$

$F W \quad$ Waste land in the catchment $\left(\mathrm{L}^{2}\right)$

$V_{S(p+1)} \quad$ Total sediment volume of a reservoir at the water level $h_{(p+1)}\left(\mathrm{L}^{3}\right)$

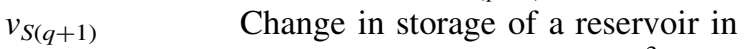
between two water levels $\left(\mathrm{L}^{3}\right)$

$p$

$q$

$\Delta h$

$A_{\text {res(p) }}$ and

$A_{\text {res }(p+1)}$

$V_{S}$

$A_{\text {res }(0)}$

$H$

$h_{0}$

$V_{0}$

$A_{\text {res }}$

$d h$

$a_{p}$

$\bar{h}$

$k^{\prime}$

$C^{\prime}, m^{\prime}, n^{\prime}$

\section{Subscripts}

$\begin{array}{ll}30 & 30 \text { min } \\ i & \text { Increment } \\ r & \text { Rainfall } \\ g & \text { Geometry } \\ \text { Crop } & \text { Cropped land } \\ \text { Fallow } & \text { Fallow land } \\ \text { TM } & \text { Thematic mapper } \\ 3,4 & \text { Landsat band } 3 \& 4\end{array}$

\section{Introduction}

In reservoir, sedimentation is a phenomenon due to which the sediment particles get deposited in the form of bed load and suspended load after separating from their origin. In fluvial hydraulics, sedimentation is an important parameter as it provides a probability of being used as a capacity predicting device in all storage zones due to which life of a reservoir can be predicted; as there is a unique relationship between capacity and life of a reservoir. To be more explicit, for a given reservoir, sedimentation is dependent on sediment yield, which is defined as the sediment discharge through a river outlet per unit catchment area per unit time (ASCE 1982). Soil erosion in the catchment is also an important parameter as the sediment yield depends on it. In order to reduce the problem corresponding with the amount of sediment particles that ultimately deposit into the reservoir after getting eroded from the catchment, attempts have been made to relate the soil erosion, sediment yield and sedimentation into the reservoir, since these three parameters deal with the life of a reservoir directly or indirectly.

The objective of this paper is to present and analyze chronological review of soil erosion, sediment yield and sedimentation of reservoir to predict the life of reservoir, highlighting the governing equations for assessment of above three parameters. Researchers can do their advanced research, using the references included in the paper for their detailed investigations.

\section{Background of soil erosion, sediment yield and sedimentation}

The erosive effect of rainfall and runoff break away the sediment particles from the catchment of the reservoir (Hudson 1975) due to intense shear stress generated by the interaction of kinetic energy of raindrop and soil surface. This phenomenon has also been explained by Wischmeir (1960). According to Roose (1980), rainfall dominates over 
the surface runoff in West Africa (256 times). Eroded sediment particles collide and break into smaller fragments. Transportation of sediment particles in a river begins when the induced shear stress by the flow overcomes the critical shear stress of the bed particles. Particles are in suspended form when the materials made up of very fine particles such as clay and silt are lifted as a result of turbulence and transported by the river. Bed load particles such as boulders are rolled and pushed along the river bed by the force of the river. When a reservoir loses its energy due to the reduction of rainfall, increasing evaporation and reduction of velocity, the sediment particles get deposited gradually in the reservoir due to gravity and consolidate over time. All the eroded sediment particles produced due to erosion in a watershed is transported out of it as there will be considerable temporary depositions in various phases and locations. However, there exists a relationship between the soil erosion and the sediment yield, which is represented using sediment delivery ratio $(\mathrm{SDR}=$ sediment yield at the catchment outlet/gross erosion in the catchment). Therefore, the sedimentation being a function of both soil erosion and sediment yield is used to determine the life of a reservoir.

\section{Problem formulations}

\section{Predicting soil erosion}

At a global scale, water erosion, is the main cause off soil degradation (Deniz et al. 2008) and about $80 \%$ of the world's agricultural land suffers from moderate to severe erosion (Ritchie et al. 2003). Prediction of erosion is the most important in soil and water conservation practices in the catchment of a reservoir. In India, soil erosion is occurring at a rate of approximately 0.16 tones $\mathrm{km}^{-1}$ year ${ }^{-1}$, of which about $10 \%$ is deposited in reservoirs and $29 \%$ is transported to the sea (Kirurhika et al. 2011). Cook (1936) identified three major variables for soil erosion and they are sensitivity of soil to erosion, potential erosivity of rainfall and runoff and soil protection afforded by plant cover. Zingg (1940) was the first to introduce mathematical equation to estimate the soil erosion losses as a function of slope steepness factor $(S)$ and slope length factor $(L)$ in the following form:

$A=C^{\prime \prime} S^{1.4} L^{0.6}$

where $C "=$ constant. Later, Smith (1941) modified the Eq. (1) by introducing a conservation factor $P$.

$A=C^{\prime \prime} S^{1.4} L^{0.6} P$

Browning et al. (1948) further modified Eq. (2) by adding soil erodibility and management factors. Wischmeier and Smith (1978) developed the universal soil loss equation (USLE) for estimating soil erosion caused by the sheet and rill erosion under specified conditions. The soil loss per unit area in unit time, $A$ is expressed as

$A=R K L S C P$

where $R=$ rainfall erosivity factor, $K=$ soil erodibility factor, $C=$ cover management factor. All the factors described in USLE are independent of each other. Primarily, USLE (index based, empirically derived model) predicts the average annual soil loss due to erosion by water for a long term, based on rainfall pattern, soil type, topography, crop system and management practices. USLE is the most widely used equation in erosion modelling (Fistikogli and Harmancioglu 2002). However, huge limitations are there to use USLE; such as in its original form it does not predict erosion in a spatial context; however this limitation is overcome when integrated with GIS. It also requires large amount of assets and time to prepare the input parameters to run the model in a new environment. Moreover, it cannot identify the events which cause large scale soil erosion as it is not event based. It also does not estimate wind, mass, tillage, channel or gully erosion as it is developed to simulate sheet and rill erosion only. To overcome these drawbacks, Renard et al. (1996) developed revised universal soil loss equation (RUSLE) and Kinnell and Risse (1998) developed a new version of universal soil loss equation (USLEM) to predict the soil loss by modifying the soil loss erosion factors. Later, RUSLE 1.06c (USDA-ARS-NSL 2003), which is land-use independent and RUSLE 2 (USDA-ARS-NSL 2003) are developed based on USLE including additional features that further analyze particular aspects of the soil erosion process. Foster (2006) compared the above three models (USLE, RUSLE 1.06c, RUSLE 2) to find their efficiencies to determine the soil loss. According to their findings, USLE does not compute deposition whereas RUSLE 1.06c computes deposition as a function of soil texture. Moreover, RUSLE 2 computes how deposition changes sediment characteristics along the slope, which in turn affects computed deposition. They concluded that RUSLE 2 is more powerful and easy-touse erosion prediction model than the other two models especially for rill and inter-rill erosion. It also presents the spatial heterogeneity of soil erosion that is too feasible with reasonable costs and better accuracy in larger areas (Angima et al. 2003). However, the drawbacks of these models are that they are not capable of calculating runoff and account for the process of sediment transport.

\section{Rainfall erosivity factor}

Wischmeier and Smith (1978) found that the energy available to erode the sediment particles from its origin during the 
rainfall is the product of kinetic energy contained within the rainfall and the intensity of the rainfall. It was found that maximum 30 min intensity of rainfall yields the best results. Hence, the rainfall erosion index $\left(E I_{30}\right)$ is defined as

$E I_{30}=\frac{K E \times I_{30}}{100}$

where $K E=$ kinetic energy of the rainfall, $I_{30}=$ maximum 30 min intensity of the rainfall. $K E$ is expressed as follows:

$K E=210.3+89 \log I$

where $I=$ rainfall intensity. The rainfall erosivity factor is defined as the summation of each rainfall erosion index within a given period in the studied area and is expressed as

$R=\frac{1}{n} \sum_{j=1}^{n}\left[\sum_{k=1}^{m}(K E)\left(I_{30}\right)_{k}\right]_{j}$

where $k=$ number of individual storm up to $m, m=$ total number of storms in a year, $j=$ number of year up to $n$ and $n=$ total number of years over which data was collected. According to Renard et al. (1996), kinetic energy is calculated as

$K E=\sum_{k=1}^{\tilde{m}} e_{r} p_{r}$

where $e_{r}=$ rainfall energy per unit depth of rainfall per unit area, $p_{r}=$ depth of rainfall for the $r$ th increment of a storm hyetograph which is divided into $\tilde{m}$ parts having constant rainfall intensity $e_{r}$, is determined using the following equation:

$e_{r}=1099\left(1-0.072^{\left(-1.27 i_{r}\right)}\right)$

where $i_{r}=$ constant intensity over the time increment.

$p_{r}=i_{r} t_{r}$

where $t_{r}=$ time of the $r$ th increment. Renard and Freimund (1994) proposed an equation to correlate the mean annual rainfall depth $\bar{P}$ with the modified Fourier index $F$, introduced by Arnoldus (1980) which is defined as

$F=\sum_{i=1}^{12} \frac{p_{i}^{2}}{\bar{P}}$

where $p_{i}$ is the mean rainfall for month $i$. It also considers the effect of seasonal variation of rainfall. When there is lack of daily rainfall data, $F$ index based on mean annual precipitation is used as a parameter to measure $R$ to which it is linearly correlated. Later, different experiments (Ferro et al. (1991, 1999); Aronica and Ferro 1997) were conducted to modify $F$ index and to correlate it with $R$. In addition, research works have been carried out to determine the effect of rainfall factor in the estimation of soil erosion by suggesting different climatic erosivity indexes (Wischmeier index 1959). Also, empirical equations of soil erosivity factor $R$ as a function of mean annual precipitation $\bar{P}$ discussed in the succeeding sections were reported by Mikhailova et al. (1997) and Torri et al. (2006). In Australia and United States, Yu and Rosewell (1996) and Renard and Freimund (1994) respectively, reported a good correlation between annual rainfall and $R$. Yu et al. (2001) concluded that the rainfall erosivity factor reflects the effect of climatic change on the soil erosion phenomenon. $\mathrm{Yu}$ (1999) compared the $R$ factor in USLE and RUSLE and concluded that the calculated R-factor using the unit energy equation is greater than that for RUSLE and the difference increases as peak rainfall tends to decrease.

To calculate $R$ factor, series of more than 20 years of rain gauge data are recommended, but this length of time series is not found in many parts of the world (Capolongo et al. 2008; Hoyos 2005; Lee and Heo 2011). Also the high-resolution rainfall data needed to directly compute the rainfall erosivity are not available for many locations. Hence, simplified methods for predicting rainfall erosivity in many countries are using readily available data. Moreover, calculations of such data are intricate and time consuming. Several researchers found that high value of annual precipitation does not necessarily produce higher values of erosivity because of variation in rainfall intensity. Panagos et al. (2015) published a map of rainfall erosivity for Europe in which maximum half hourly intensity instead of $\mathrm{I}_{\max 30}$ was used. Auerswald et al. (2015) studied the deficiencies of the map produced by Panagos et al. (2015) and reported that the values of this map contain some bias. The temporal resolution of the rainfall data was insufficient, which likely underestimates rainfall erosivity by about $20 \%$. Different time periods had not been taken into account which can modify rainfall erosivity by more than $50 \%$. Also use of precipitation data instead of rainfall data causes the overestimation of rainfall erosivity in areas with significant snowfall. Moreover, the seasonal variation of rainfall erosivity is not considered, which restricts using of the erosivity map for erosion prediction in many cases. Maetens et al. (2012) conducted studies in Europe and Mediterranean by reviewing data from 227 stations and 1056 soil erosion plots to predict the effect of land use on annual soil erosion, annual runoff and annual runoff coefficient. They concluded that the soil loss does not correlate better with erosivity indices than with total rainfall. In addition, some discussions on prediction of $R$ are also available elsewhere (Lee and Heo 2011; Oliveira et al. 2013b).

\section{Soil erodibility factor}

The soil erodibility factor $K$ is affected by intrinsic soil properties. The main soil properties affecting $K$ are soil 
texture, organic matter, structure and permeability of the soil profile. $K$ shows to what extent soil can be detached by rainfall splash and surface flow (Zhang et al. 2008). It depends on the local soil properties including physical, chemical, biological and mineralogical and can be determined through sample analysis of the soil or from a soil map or pedological survey of the site or through a combination of these. In RUSLE, all properties are categorized into two groups: properties that impact rate of infiltration, mobility of water through soil and water storage capacity; and properties that influence dispersion, detachability, abrasion and movement of soil particles due to rainfall and runoff (Wischmeier and Mannering 1969; SWCS 1995; Soil Survey Staff 1997). $K$ may have temporal as well as spatial variation for a particular type of soil. According to Wischmeier and Smith (1978), $K$ factor (crop management factor) may be calculated for the unit plot (standard plot for which $L S=1$ and $C P=1$ ) by the following equation:

$K=\frac{A}{R}$

Renard et al. (1996) proposed a formula to determine the $K$ factor on the basis of global data of measured $K$ values, obtained from 225 soil classes.

$K=0.0034+0.0405 \times \exp \left[-0.5\left(\frac{\log d_{g}+1.659}{0.7101}\right)^{2}\right]$

where

$d_{g}=\exp \left(\sum f_{i} \ln \left(\frac{d_{i}+d_{i-1}}{2}\right)\right)$

where $d_{g}$ is the geometric mean particle size, $d_{i}$ is the maximum diameter, $d_{i-1}$ is the minimum diameter and $f_{i}$ is the corresponding mass fraction. $K$ may be accurately estimated from soil loss data spread over the prolonged period, though it is very expensive, time consuming and impractical for many situations (Renard et al. 1997). Geostatistical methods like sequential Gaussian can be used to simulate $K$ from the soil of the study area, which minimizes risk and takes proper land management practices with useful information (Wang et al. 2001). Breshears et al. (2003) commented that there are several methods of estimating $K$ such as measuring soil physiochemical properties, scouring, rainfall simulation, plot experiment etc. Some researchers (Zhang et al. 2007) pointed out that soil erodibility may be influenced by the presence of lime. Lime content increases aggregate stability, resulting in a decreased $K$ (Zhang et al. 2008). Vaezi et al. (2008) directly related the lime content to $K$. At present, long term monitoring of soil loss from natural runoff plots is the best method to estimate $K$ for a given soil (Kim et al. 2005).
However, some important discussions on $K$ factor of RUSLE are also available elsewhere (Breshears et al. 2003; Kim et al. 2005; Zhang et al. 2008; Vaezi et al. 2008).

\section{Topographic factor}

The effect of topography of land on soil erosion can be reflected by $L$ and $S$ factor in USLE. Due to the difficulty in the calculation of $L S$ factor, an average $L S$ value is assumed for entire region. This factor can be calculated in various ways depending on unit preferences and available data. According to Risse et al. (1993), Hann et al. (1994) and Biesemans et al. (2000), the overall efficiency of USLE model depends mainly on the topographic factor $(L S)$ and the crop management factor $C$.

Different empirical relations are used to determine this factor. Combining all the findings by the researchers (Zingg 1940; Smith and Whitt 1948), the following expression represents the relation of $L S$ factor with soil erosion

$L S=\left(\frac{\lambda}{22.13}\right)^{m^{\prime \prime}}\left(\frac{\sin \theta}{\sin 5.143^{\circ}}\right)^{n^{\prime \prime}}$

where $m^{\prime \prime}$ and $n^{\prime \prime}=$ fitted regression coefficients. According to Wischmeier and Smith (1978), the product of $L$ and $S$ is given by the following equation:

$L S=\left(\frac{\lambda}{22.13}\right)^{k^{\prime}}\left[65.41 \sin ^{2} \theta+0.065\right]$

where $\lambda=$ field slope length, $k^{\prime}=$ exponent factor ranging from 0.2 to 0.5 and $\theta=$ angle of slope.

It was concluded from the findings of that increase in slope length and slope steepness cause higher velocities in overland flow and correspondingly higher erosion. Liu et al. (1994) stated that various functional forms (linear, power or polynomial forms) of soil loss predictive equations produce identical values of soil loss caused on hillsides by rainfall and runoff for slope up to $25 \%$. However, they provide different values of soil loss beyond this slope gradient. Some studies have concluded that slope steepness rather than slope length affects the value of the topography factor (McCool et al. 1987; Van et al. 2004). Computing of length slope gradient factor ( $L S$ factor) of USLE/RUSLE equation is very difficult. According to Mitasova et al. (1996), this drawback can be minimized by modifying $L S$ factor where the influence of profile convexity/concavity using segmentation of irregular slopes is incorporated. Oliveira et al. (2013a, b) gave an idea to use Shuttle Radar Topography Mission (SRTM) data for computing RUSLE topographic factor in absence of topographic information. Though the effect of slope is considered in USLE, study can be conducted to examine the effect of slope on the determination of USLE- $K$ factor. 


\section{Crop management factor}

$C$ factor (crop management factor) is the ratio of soil loss from cropped land under specified conditions $\left(A_{\text {crop }}\right)$ to the corresponding clean-tilled continuous fallow $\left(A_{\text {fallow }}\right)$. It is influenced by various factors like specific vegetation cover, rotation sequence, overall functions of managing measures and the distribution of erosive precipitation in different vegetative period of crop. It is expressed as

$C=\frac{A_{\text {crop }}}{A_{\text {fallow }}} \times 100 \%$.

In USLE, the crop management factor is derived based on empirical equations with measurements of ground cover, aerial cover and minimum drip height whereas in the RUSLE, the effect of crop and management is analyzed in more detail as the $C$ factor is composed of subfactors such as impact of previous cropping and management, the protection of soil surface by vegetative canopy, reduction in erosion due to surface cover and surface roughness. For specific crop rotations, the approach to measure $C$ value by field experiments is very time-consuming.

Takken et al. (1999) concluded that the relationships between vegetation and erosion could be further improved considering the distribution of vegetation. Important discussions on factor $C$ are also available in different places (Cai et al. 2000; Donald et al. 2003). Constant values of the RUSLE $C$ factor, produced in earlier studies, are usually used to evaluate soil erosion in watersheds. These values, however, do not accurately represent vegetation variation, particularly in large areas, which can result in mistaken estimates of soil loss. To avoid this problem many studies have been conducted to determine $C$ factor by using satellite images for which various sub factors such as land cover classification map, image bands, ratios of image bands, vegetation index and vegetation coverage are needed to process using remote sensing techniques (Manoj and Umesh 2000; Wang et al. 2002; Vrieling 2006). Large effort has been made on calculating and mapping the $C$ factors for use in soil erosion modelling by means of Geographic Information System, remote sensing data and spectral indices (de Asis and Omasa 2007; Wang et al. 2002). The normalized differenced vegetation index (NDVI) derived from multispectral images is currently one of the most common environmental covariates of vegetation in order to monitor and analyze vegetation, its properties, and spatial and temporal changes (Wang et al. 2002; Lin et al. 2002). As a function of the NDVI, the fractional vegetation cover (FVC) provides information on the percentage of vegetation cover. The NDVI is an indicator of vegetation growth, for which Landsat-ETM $\left(L_{T M}\right)$ is given by the following equation:
$N D V I=\frac{L_{T M 4}-L_{T M 3}}{L_{T M 4}+L_{T M 3}}$

The value of NDVI ranges between -1.0 to +1.0 . According to Van Leeuwen and Sammons (2004), the following formula is used to generate $C$ factor

$C=e^{(\alpha((N D V I) /(\beta-N D V I)))}$

where $\alpha$ and $\beta$ are two dimensionless parameters that determine the shape of the curve relating NDVI and the $C$ factor. Van der Knijff et al. $(1999,2000)$ found that the values of 2 and 1 selected for the parameters $\alpha$ and $\beta$ produces good result for the value of crop management factor. These methods employ regression model to make correlation analysis between $C$ factor values measured in field or obtained from guide tables and NDVI values derived from remotely sensed images. The goal of regression analysis is to estimate the unknown values of dependent variable based upon values of an independent variable using a mathematical model. However, under tropical climate conditions, the $C$ factor tends to be higher than that calculated by these methods for the same vegetation cover. Therefore, a new method considering the variation of climatic conditions for calculating the RUSLE $C$ factor, based on NDVI rescaling, was proposed by Durigon et al. (2014). Very few research works were conducted on the crop rotational scheme. So investigations should be carried out considering the crop rotational scheme and positioning of crops in their rotation to assess the variation of the $C$-factor values.

\section{Practice factor}

$P$-factor represents the effect of surface conditions like contouring, strip cropping and terraces on flow paths and hydraulics. This variable is set equal to 1 in military land management applications. However, different $P$ factor scenarios may be considered to determine the various effects of different management techniques on soil-loss estimates. The documentations of softwares like FLUVIAL-12 (Chang 2006) and SWAT (Neitsch et al. 2005) describe the modelling approaches for the prediction of USLE factors.

The evaluation of each subfactor of USLE or RUSLE is difficult because of many possible combinations, and the time spent with data acquisition and analysis. However, the advantage of predicting soil loss by using either of these methods is that over long period of time and large area, overestimations and underestimations can compensate each other, resulting in a good overall assessment of total soil loss. Schonbrodt et al. (2010) and Gabriels et al. (2003) discussed different issues and problems associated with USLE/RUSLE. Among the different techniques to predict 
USLE, confusions are there regarding the methodology to be used for the prediction of different factors. It depends on the site condition and availability of data. However, all the values can't be validated due to the lack of field data. Therefore, detailed field surveys are necessary for the development of different USLE factors.

\section{Models for predicting soil erosion}

Models of estimating the soil erosion can be classified into three categories: empirical models, physical models and conceptual models. Empirical models are developed from the statistical analysis on the information obtained from experimental measurement or field measurement, specially used for identifying the sources of sediments (Merritt et al. 2003). Therefore, empirical models are used widely in catchment scale as they are applied uniformly over the region. However, they are unable to analyse the dynamics of sediment erosion and deposition in the watershed as it contains less amount of input data.

Physically-based models are developed based on the conservation of law of mass and energy to derive partial differential equations for describing runoff and sediment yield induced by independent rainfall events in the watershed (Bennett 1974). They are mostly used to describe the effect of land surface characteristics such as topography, slope, vegetation, soil, as well as climate parameters including precipitation, temperature and evaporation (Legesse et al. 2003). But the disadvantage of this type of model is the requirement of large amount of data.

Conceptual models, which are mixture of empirical and physically-based models, provide an indication of qualitative as well as quantitative processes within a catchment without considering process interactions. Table 1 represents a brief description of empirical, physical and conceptual models for predicting soil erosion.

Various empirical equations of soil loss due to erosion were reported by the researchers (Van Doren and Bartelli 1956; Adinarayana et al. 1999 and Veihe et al. 2001). Lu et al. (2004) concluded that the methods based on erosion plots have drawbacks in respect of cost, representativeness and reliability of the resulting data. Hence, these methods cannot provide spatial distribution of soil erosion loss in complex environments. Presently, the hydrological models are being used incorporating the topographical features of terrain, land use and soil characteristics from remote sensing satellites and GIS (Star et al. 1997). Investigators (Mitasova et al. 1996; Yitayew et al. 1999; Millward and Mersey 1999; Fernandez et al. 2003; Lim et al. 2005; Bayramin et al. 2008) combined the USLE/RUSLE with GIS to estimate the magnitude and spatial distribution of soil erosion. The combined use of GIS with erosion models has been proved to be an effective approach for estimating the magnitude and spatial distribution of soil loss. Manual calculation allows the determination of soil loss only from the land as a whole. Therefore, the calculation of subfactors in GIS environment gives the possibility of determining the total soil loss from the whole plot, as well as from each network element. Moreover, this approach helps to implement erosion control measures only in those parts of the land that are truly at risk. However, important discussions on the evaluation of subfactors of USLE/RUSLE by using GIS, are also available elsewhere (Fernandez et al. 2003; Fu et al. 2006; Lim et al. 2005).

Jetten et al. (1999) conducted their studies by combining a raster-based approach to spatial distribution, with a fully dynamic approach to predict time-variable hydrographs. They concluded that every soil erosion model has limitations in terms of its representation of erosion processes. One source of the positional error might lie with flow path delineation while another source of uncertainty is the high spatial variability of parameters which are assumed constant by the model. Baskan et al. (2010) carried out investigations to assess the application of the sequential Gaussian simulation (SGS) for mapping of soil erodibility factor of the USLE/RUSLE methodology coupled with spatial uncertainty. Due to the absence of sediment data over a period of time, ${ }^{137} \mathrm{Cs}$ (Cesium) technique can be used to quantify the soil erosion very quickly and accurately. Using this technique, large number of experiments have been conducted in different regions for predicting soil erosion (Kosmas et al. 2001; Li and Poesen 2003; Fukuyama et al. 2005; Yang et al. 2006; Zhang et al. 2006, 2008).

\section{Predicting sediment yield}

\section{Sediment yield from a storm}

The determination of SDR is necessary to predict sediment yield at the outlet of catchment. Walling (1983) and Kinnell (2004) discussed the limitations of using SDR to determine sediment yield. Certain other empirical equations to predict SDR discussed in the succeeding sections, were reported (Horowitz 2003; Schmidt and Morche 2006). In most of the applications, where SDR has been used to determine sediment yield, it is assumed that the value of SDR is constant whereas in practices they have been shown to vary for different storm events. SDR also possesses high level of uncertainty since it is a complex function of space and time.

Pacific Southwest Inter-Agency Committee first developed the semi-quantitative model (PSIAC) in 1968 to predict the sediment yield. The methodology works well even with less amount of data and includes the effect of gully erosion and topography. However, this semi- 
Table 1 Different models for predicting soil erosion (Merritt et al. 2003)

\begin{tabular}{|c|c|c|}
\hline Empirical Models & Physically Based Models & Conceptual Models \\
\hline $\begin{array}{l}\text { Musgrave equation } \\
\text { (Musgrave 1947) } \\
\text { PSIAC Method } \\
\text { (Pacific Southwest Interagency Committee 1968) } \\
\text { USLE } \\
\text { (Wischmeier and Smith 1978) } \\
\text { SLEMSA } \\
\text { (Elwell 1978) } \\
\text { SEAGIS } \\
\text { (DHI 1999) } \\
\text { RUSLE } \\
\text { (Renard et al. 1996) } \\
\text { SEDNET } \\
\text { (Prosser et al. 2001c) } \\
\text { RUSLE2 } \\
\text { (Foster et al. 2002) } \\
\text { PESERA } \\
\text { (Kirkby et al. 2004) }\end{array}$ & $\begin{array}{l}\text { ANSWERS } \\
\text { (Beasley et al. 1980) } \\
\text { CREAMS } \\
\text { (Knisel 1980) } \\
\text { GUESS } \\
\text { (Rose et al. 1983) } \\
\text { EPIC } \\
\text { (Williams et al. 1984) } \\
\text { TOPOG } \\
\text { (O'Loughlin 1986) } \\
\text { WEPP } \\
\text { (Nearing et al. 1989) } \\
\text { KINEROS } \\
\text { (Woolhiser et al. 1990) } \\
\text { GUEST } \\
\text { (Misra and Rose 1990) } \\
\text { dUSLE } \\
\text { (Flacke et al. 1990) } \\
\text { EROSION2D } \\
\text { (Schmidt 1991) } \\
\text { PERFECT } \\
\text { (Littleboy et al. 1992) } \\
\text { LISEM } \\
\text { (De Roo et al. 1994) } \\
\text { KINEROS2 } \\
\text { (Smith et al. 1995) } \\
\text { EUROSEM } \\
\text { (Morgan et al. 1998) } \\
\text { WATEM/SEDEM } \\
\text { (Takken et al. 1999; Feng et al. 2010) } \\
\text { MIKE-11 } \\
\text { (Hanley et al. 1998) }\end{array}$ & $\begin{array}{l}\text { Sediment concentration graph (Johnson 1943) } \\
\text { Renard-Laursenn Model } \\
\text { (Renard and Laursen 1975) } \\
\text { Unit Sediment Graph } \\
\text { (Rendon-Herrero 1978) } \\
\text { Instantaneous Unit Sediment Graph } \\
\text { (Williams 1978) } \\
\text { AGNPS } \\
\text { (Young et al. 1989) } \\
\text { EMSS } \\
\text { (Vertessey et al. 2001) } \\
\text { HSPF } \\
\text { (Johanson et al. 1980) } \\
\text { IQQM } \\
\text { (DLWC 1995) } \\
\text { LASCAM } \\
\text { (Viney and Sivapalan 1999) } \\
\text { SWRRB } \\
\text { (USEPA 1994) }\end{array}$ \\
\hline
\end{tabular}

quantitative approach is applied only in the planning purposes of dam construction and also for the analysis of the effect of the hydraulic structures on downstream sediment budgets.

Williams (1975) developed the USLE (Eq. 1) by replacing the rainfall energy with runoff which is expressed in the following form:

$Y=11.8\left(Q \times q_{\tilde{p}}\right)^{0.56} K(L S) C P$

where $Y=$ sediment yield from an individual storm in a given day and $q_{\tilde{p}}=$ peak rate of runoff volume. It was concluded that MUSLE eliminates the need of SDR and it may be used for individual storm event. Many researchers used MUSLE model to estimate sediment yield (Williams and Berndt 1977; Arekhi and Rostamizad 2011) in different parts of the world along with different revisions.

\section{Sediment yield from watershed}

The most widely used common procedures to predict the sediment yield from a watershed are to use simultaneously flow duration curve as well as sediment rating curve (Crawford 1991), reservoir sedimentation survey data (Verstraeten and Poesen 2000) and estimation of soil erosion and sediment delivery ratio. Different empirical equations are there to calculate the sediment yield at the outlet of a reservoir. Khosla (1953) developed the equation to predict the volume of sediment yield in the following form: 
$Q_{S V}=0.00323 A_{\text {catch }}^{0.72}$

where $Q_{S V}=$ volume of sediment yield per year and $A_{\text {catch }}=$ catchment area. But the drawback is that the equation underestimates the rate of sedimentation. Flaxman (1972) developed a more complicated empirical model that relates sediment yield to mean annual climate, watershed slope and soil characteristics. Later Dhruvnarayana and Ram (1983) developed the sediment yield equation in the following form:

$Q_{S}=5.5+11.1 Q$

where $Q_{s}=$ annual sediment yield rate and $Q=$ annual runoff volume. Garde and Kothyari (1987) estimated the mean annual sediment yield $\left(Q^{\prime}\right)$ from the large catchment and proposed the equation in the following form:

$Q^{\prime}=1.182 \times 10^{-6} \times \bar{P}^{1.29} \times A_{\text {catch }}^{1.03} \times D_{d}^{0.40} \times S^{0.08} \times C^{2.42}$

where $D_{d}=$ drainage density and

$C=\left(\frac{0.8 F A+0.6 F G+0.3 F F+0.1 F W}{A_{\text {catch }}}\right)$

$F A$ denotes the arable land in the catchment and $F G$ is the grass land, $F F$ is the forest land and $F W$ is the waste Land.

FAO (1997) performed traditional catchment experiments to measure the sediment yield at the outlet of a catchment and to assess the impact of changing land management practices on this yield. However, the traditional models are unable to predict the sediment yield accurately due to their inabilities to simulate accurately runoff rates and amounts, i.e. the hydrologic response at the basin scale. Suresh (2000) identified the factors which affect the sediment yield as land use, soil type, catchment size, climate and rainfall. Later Krishnaswamy et al. (2001) and Renschler and Harbor (2002) determined correlation between sediment yield and watershed area. Moreover, Sun et al. (2002), Paringit and Nadaoka (2003), Jain et al. (2005) combined geographic information system with the rainfall-runoff model, the soil erosion model and the sediment transport model to compute the runoff and sediment yield in the watershed and made it easy to utilize the huge amount of geographic and hydrological parameters simultaneously in a watershed. Dendy and Bolton (1976) concluded from the empirical studies that sediment yield decreases substantially as watershed area increases whereas Shen and Julien (1993) confirmed the conclusions made from the above intuition that the SDR may reach $10 \%$ as watershed area reaches $100 \mathrm{~km}^{2}$. However, this relation has some constraints as it encompasses huge amount of variables and has a limited theoretical basis. de Vente et al. (2007) reported that the sediment yield increases and decreases as a function of watershed area. The non linear relationship exists between them due to the spatial variation of topography, land use land cover or climate. The inverse relationship of SDR to watershed size has been assigned to longer travel distances (Parsons et al. 2006), longer travel times (Williams 1975) and lower average land slopes (Boyce 1975). Verstraeten and Poesen (2001) suggested that it might be more reliable to use sediment volume than sediment mass for sediment yield assessments. However, the use of reservoir sedimentation as a predicting tool of sediment yield accounts for some drawbacks such as the total deposition volume does not give information about temporal variation of sediment production and the calculated sediment yield is averaged over an extended time (Alatorre et al. 2012). Table 2 represents the empirical, physical and numerical models for predicting sediment yield. Numerical models do water routing on the basis of equal surfaces whereas physical based models do it on the basis of equal volumes for reservoirs with two outlet structures such as weir and orifice. In comparison to empirical and physical models, numerical models provide good prediction of shape and magnitude of the effluent sediment concentration graph. Verstraeten and Poesen (2002) carried out their studies to find the possibilities and limitations of the use of sedimentary deposits for determining the sediment yield in small water bodies. It was reported that the sediment depositions need to be converted to the sediment masses using the dry sediment bulk density. The measured sediment masses need to be corrected for assessing the trap efficiency of the small retention ponds to minimize the error to predict the sediment yield. The drawback of this method is that it is inadequate due to unavailability of data and it is incorporated with bedload transport which is very difficult to measure through sampling.

Laronne and Mosley (1982) presented a review on erosion and sediment yield whereas Araujo and Knight

Table 2 Different models for predicting sediment yield

\begin{tabular}{ll}
\hline Physically based models & Numerical models \\
\hline DEPOSITS & STEP \\
(Ward et al. 1977) & (Verstraeten and Poesen 2001)
\end{tabular}

CSTRS

(Wilson and Barfield 1984)

BASIN

(Wilson and Barfield 1985)

1986 EPA Urban Methodology

(Driscoll 1986)

SHETRAN

(Ewen et al. 2000) 
(2005) reviewed sediment yield measurement in different scales and concluded that the approaches for sediment yield measurement bear a much closer relationship to the temporal than to the spatial resolution.

\section{Predicting sedimentation}

Due to construction of dam, the transported sediments get deposited into the reservoir, causing reduction of the storage capacity. Analysis of sediment distribution is important to tackle the problems such as rising of bed level, increasing flood levels and entry of sediments into the reservoir. The sediment deposition can be determined directly based on either the analysis of the samples taken from geological drilling in the reservoir (Lee 1997) or in situ cross-section elevation measurements. But the disadvantages of these two methods are expensive and time consuming. Heinemann (1981), Graf (1984), Morris and Fan (1998) and Subramanya (2008) discussed the sedimentation phenomenon in the proper section of their books. Also, due to its practical importance, the Indian Standard (1994) recommended the estimation of sedimentation in reservoir at different elevations by the area increment and area reduction method.

\section{Trap efficiency}

Brown (1943) was the first to recognize the important feature of sedimentation into the reservoir, proposing a term trap-efficiency. The trap-efficiency is defined as the percentage of incoming sediments that is retained into the reservoir. It is simple to use, specially when the runoff data are missing. A curve was developed to correlate trap-efficiency with capacity- watershed area ratio. Churchill (1948) established a relationship between trap-efficiency and reservoir sedimentation index which is defined as residence time divided by the mean flow velocity through the reservoir. Brune (1953) developed a graphical curve (Brune curve) consisting of three curves; one median and two envelopes (fine and coarse sediment) to determine the trap-efficiency of a reservoir. 44 records of reservoir trapefficiency and the factors affecting trap-efficiency were studied. It was concluded that the capacity-inflow ratio has a good correlation with trap-efficiency in comparison to capacity-outflow ratio but it may vary with the location of outlets and reservoir operating procedure. Borland (1971) concluded that Churchill curve is superior to Brune curve for estimating the trap-efficiency of desilting and partially dry reservoir. Though Churchill curves give better result than Brune curves to predict the trap efficiency of a reservoir, yet it is inconvenient to obtain the input data for determining the sedimentation index. Hence, Brune curve is used mostly in comparison to Churchill curve. According to Vanoni (1975), trap-efficiency depends on sediment characteristics, stream flow velocity and reservoir operation. Rowan et al. (1995) showed that the trap efficiency calculated using Heinemann curve (1981) is $30 \%$ lower in comparison to Brown curve (1944) for one reservoir, whereas with Brune (1953), it was in between the two. Figure 1 shows different curves for predicting trap-efficiency of a reservoir. Many empirical studies (Dendy 1974 and Gill 1979) correlated water inflow, reservoir storage capacity and trap-efficiency. Verstraeten and Poesen (2000) developed an empirical formula to estimate trapefficiency of a reservoir but it needs more input data. In case of empirical models, prediction of trap efficiency for conditions without permanent storage are not accurate in contrast to physically based as well as numerical models, due to the inability of these empirical models to simulate consecutive runoff events.

Garg and Jothiprakash (2010) investigated the efficiency of conventional empirical approaches along with soft computing data-driven techniques such as artificial neural network (ANN) and genetic programming (GP) to estimate the reservoir trap-efficiency by incorporating reservoir age. It was found that ANN model results are better than conventional empirical methods but inferior to GP. Various investigators (Neil and Mazari 1993; Verstraeten and Poesen 1999) have concluded that sediment trap efficiency is an important parameter to assess sediment yield when sediment deposits in reservoirs. If trap-efficiency is not accounted for in such studies, sediment yield will be underestimated. Numerous studies on trap-efficiency of different reservoirs have been carried out by various investigators (Heinemann 1981; Villegas and Schnoor 2009; Stephen et al. 2013).

\section{Sediment distribution}

WCD (2000) reported that reservoirs all around the world are filled up approximately at a rate of $1 \%$ every year. The annual storage loss of reservoir in terms of percentage for India is 0.46 (Chaudhry et al. 2014). The distribution of sediment particles at different elevations is based on factors like quantity of stream flow and mobility of sediment particles, physical and chemical properties of sediment and the operational procedure of a reservoir (USBR 1987). Churchill (1948) was the first to predict the reservoir sedimentation rate by relating the reservoir capacity loss with basic hydrodynamic parameters through empirical curves. Most convenient methods to determine the sedimentation of a reservoir are the direct measurement by hydrographic survey and the indirect measurement using the inflowoutflow records of a reservoir. But these methods are inconvenient, time consuming and uneconomical According to the traditional hydrographic survey, the storage 
Fig. 1 Curves for predicting trap efficiency
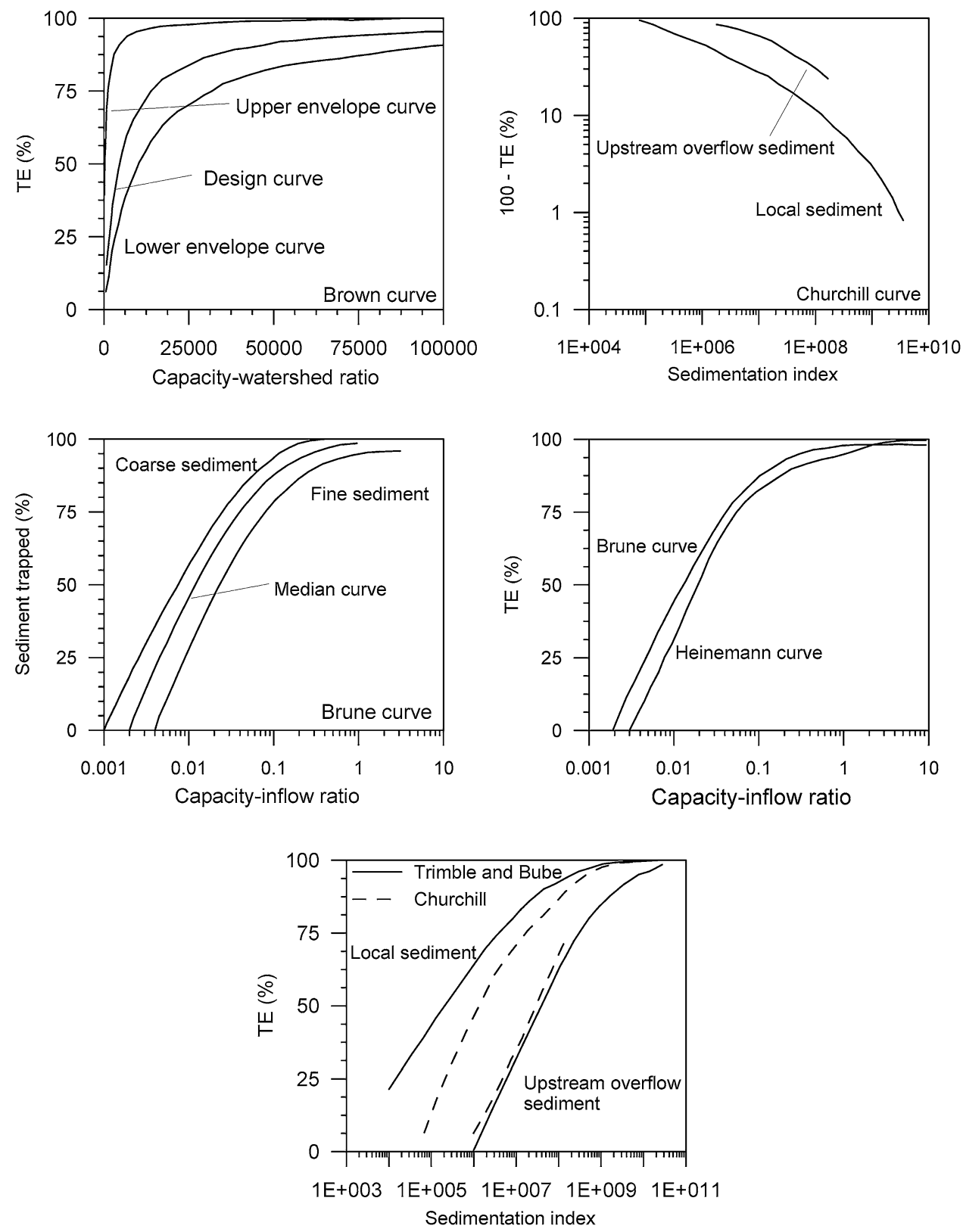

$V_{S(p+1)}$ of a reservoir at the water level $h_{p+1}$ is expressed in the following form:

$V_{S(p+1)}=\sum_{q=0}^{p} v_{S(q+1)}$

where

$v_{S(q+1)}=\left(A_{r e s(p)}+A_{r e s(p+1)}+\sqrt{A_{\operatorname{res}(p)} A_{\operatorname{res}(p+1)}}\right) \Delta h / 3$

$\Delta h=$ difference between two consecutive water levels of a reservoir, $A_{\text {res }(p)}$ and $A_{\text {res }(p+1)}=$ corresponding water surface area of $h_{p}$ and $h_{(p+1)}$; and $v_{S(q+1)}=$ change in storage of a reservoir in between two water levels $\Delta h$. Figure 2 shows the schematic of sediment distribution in the traditional method. Cristofano (1953) developed the area increment method to calculate the surface area of reservoir at any depth. It is based on the assumption that the volume of deposited sediment per unit height of reservoir is constant. The following expression represents the area increment method to predict the total sediment volume in the reservoir:

$V_{S}=A_{\text {res }(0)}\left(H-h_{0}\right)+V_{0}$

where $V_{S}=$ total sediment volume, $A_{\text {res }(0)}=$ original reservoir surface area at depth $h_{0}, H=$ maximum depth of 


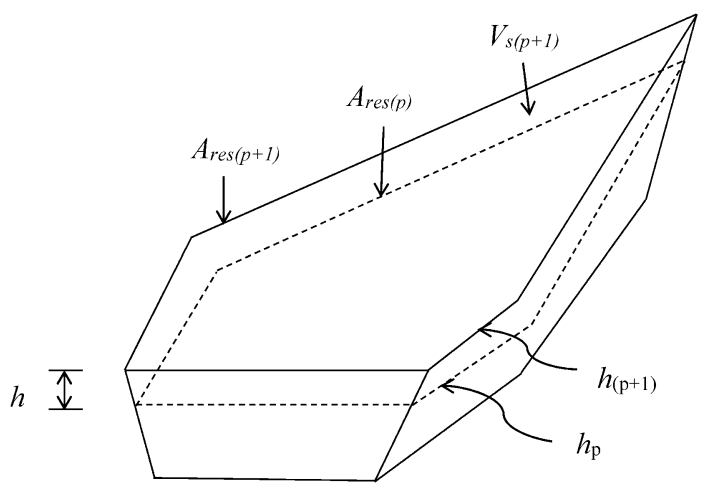

Fig. 2 Schematic of sediment distribution in the traditional method

Table 3 Values of $C^{\prime}, m^{\prime}$ and $n$ ' for four types of reservoirs (Borland and Miller 1958)

\begin{tabular}{lccc}
\hline Type & $C^{\prime}$ & $m^{\prime}$ & $n^{\prime}$ \\
\hline I & 3.4170 & 1.5 & 0.2 \\
II & 2.3240 & 0.5 & 0.4 \\
III & 15.882 & 1.1 & 2.3 \\
IV & 4.2324 & 0.1 & 2.5 \\
\hline
\end{tabular}

Table 4 Classification of reservoir (Borland and Miller 1958)

\begin{tabular}{lll}
\hline$M$ & Reservoir type & Standard classification \\
\hline $3.5-4.5$ & Lake & I \\
$2.5-3.5$ & Flood-plain-foothill & II \\
$1.5-2.5$ & Hill & III \\
$1.0-1.5$ & Gorge & IV \\
\hline
\end{tabular}

reservoir, $h_{0}=$ sediment depth at dam's wall position (new zero depth of the reservoir) and $V_{0}=$ original reservoir capacity at depth $h_{0}$. The Borland and Miller method (1958), also known as the area reduction method, was developed to express the sediment distribution at any level $\left(h_{0}\right)$ above the bed. The equation of area reduction method is expressed as

$V_{S}=\int_{0}^{h_{0}} A_{r e s} d h+\int_{h_{0}}^{H} k^{\prime \prime} a_{p^{\prime}} d h$

where $A_{\text {res }}=$ reservoir surface area at any depth $h$, $d h=$ incremental depth, $k^{\prime \prime}=$ constant of proportionality for converting relative areas $a_{p^{\prime}}$ to actual areas. The equation of relative area is expressed as

$a_{p^{\prime}}=C^{\prime} \times \bar{h}^{m^{\prime}} \times(1-\bar{h})^{n^{\prime}}$

where relative depth $\bar{h}=h_{0} / H$; and $C^{\prime}, m^{\prime}$ and $n^{\prime}$ are coefficients, values of which depend on the type of the reservoir as presented in Table 3. The classification (gorge, hill, flood plain-foot hill and lake) of reservoir depends on the value of shape factor $M . M$ is the reciprocal of the slope of the best-fit line resulted from the graph of reservoir elevation above bed as ordinate versus reservoir capacity at that elevation as abscissa on a log-log scale. Table 4 represents the classification of reservoir and Figs. 3 and Fig. 4 show the schematic of sediment distribution in the area increment method and area reduction method. However, in estimating reservoir sedimentation and accumulation, a number of uncertainties arise. These are related to quantity
Fig. 3 Schematic of sediment distribution in the areaincrement method
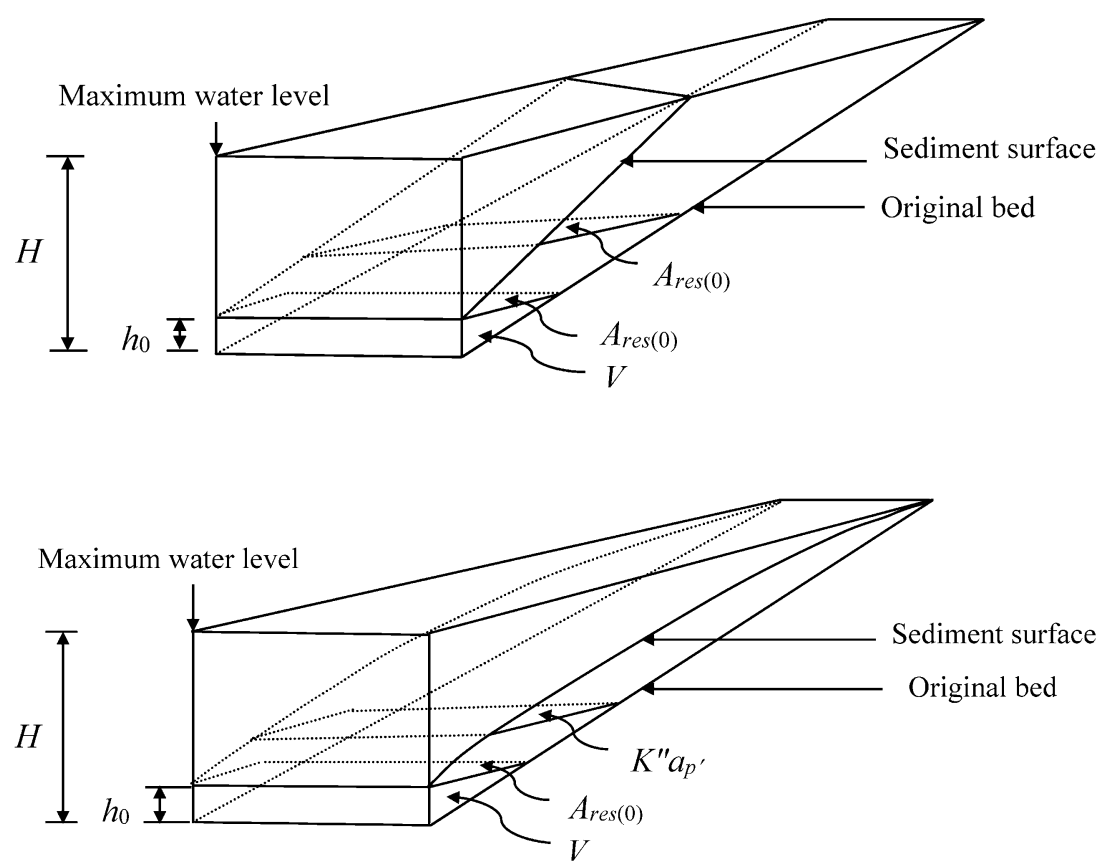

Fig. 4 Schematic of sediment distribution in the areareduction method 
of streamflow, sediment load, sediment particle size, and specific weight, trap efficiency, and reservoir operation.

A number of mathematical models based on the equations of motion and continuity for water and sediment for predicting reservoir sedimentation have been developed by different investigators (Chen et al. 1978; Soares et al. 1982; and Morris and Fan 1998). Al-Taiee (2005) used a methodology to deal with the distribution of sediment particles on the bed of reservoir. But the above method does not provide good results, in case the maximum water level of reservoir is increased or the accumulated sediment particles are dredged. Physiographic soil erosion-deposition model (PSED), developed by Chen et al. (2006) is capable to predict sediment yield in the watershed and the sediment deposition in the reservoir. In this model, the computational cells are categorized into land form and river system by using the continuity equations for overland flow and suspended sediments. An empirical method independent of climate was developed by Md. Habili and Heidarpour (2010) relating the sediment distribution with the sediment volume and original reservoir characteristics. But they may not give good results if the accumulated sediments into the reservoir are dredged or maximum water level of the reservoir is increased.

Moldovanu et al. (2011) developed SEDCONTROL, depending on various factors like size and geometric shape of reservoir, geological structure of the hydrological basin etc. to estimate sediment deposition into the reservoir. The advantage of this approach is that it measures sediment deposition at a fixed position which is not influenced by the inevitable errors of mobile systems and also by the sedimentary material deposits on the walls. In addition, nowadays satellite data are used, which is cost and timeeffective tool to determine the area-elevation and capacity of a reservoir (Jain and Goel 2002) and it has no influence on normal operation of a reservoir. Compared to other conventional methods, they are considered as superior so far as the change of water spread area of the reservoir after the deposition of sediment and distribution pattern of sediment at different elevations are concerned. However, the information of the dead storage capacity could not be obtained from remote sensing, but it could be obtained from hydrographic survey. Computer programs such as HEC-6 (U.S. Army Corps of Engineers 1993), Gstars3 (Yang and Simoes 2002), FLUVIAL and TABS (Morris and Fan 1998) have been developed to predict sediment distribution in reservoirs based on numerical solution using continuity, momentum and transport equations for both water and sediment.

\section{Bed level}

For monitoring the erosion and siltation processes in watershed and reservoir, one must have the knowledge of the changes of the shape of the reservoir bottom. The shape of the reservoir bed determines the depths in the reservoir as well as the volume of the accumulated water in the reservoir. The depth of accumulated sediment in a reservoir for a known period can be measured by using echosounder (an ultrasound source as emitter and transducer as receiver) and other electronic devices since the normal sounding operations give erroneous results for large depths. ElManadely (El-Manadely 1991) developed a one-dimensional numerical model on the basis of momentum and sediment continuity equation to estimate change in the river bed profile in the longitudinal direction. Various publications are also there to determine the bed level of a reservoir by different techniques, such as Langland and Hanely (1997); Ceylan et al. (2011). Van Rijn (2006) mentioned that there are three methods for accurate measuring of bed level; bed level detection in combination of mechanical and DGPS (Differential Global Positioning System), bed level detection with acoustic bed level detectors (single and multi beam echo sounders) and bed level detection optically. Fuska et al. (2014) developed the method of reservoir bottom mapping for the determination of water depth and volume in GIS environment using 3D models of the reservoir bottom in raster and vector formats. However Moody's method (IS 5477-PART 2 1994) is also used to determine the new zero elevation which is defined as the raised bed level of the reservoir due to the deposition of the sediments.

\section{Scope of future work and conclusion}

This review, a preliminary research and also limited to some extent as it tries to cover huge periphery of soil erosion, sediment yield and sedimentation of a reservoir. It will help the readers to take prior consideration for assessing the soil erosion and sedimentation in reservoir.

Large numbers of research works have been done on soil erosion, sediment yield and sedimentation in various reservoirs and all research works guide us to understand the practical importance of the sedimentation problem. However, it remains unexplored from different aspects. Research on erosion process, sedimentation as well as their modelling approaches is still ongoing. Models that are capable to correlate both erosion and sedimentation at the basin scale have not been explored for reservoir. Different approaches may be developed to predict the effect of future climate change on sedimentation of reservoir. Relationships between upstream and downstream of a reservoir can be established by studying the complex phenomena of soil erosion, sediment yield and sedimentation of a reservoir. Research on water quality impact of sediments on water availability is also expected. 
Acknowledgments The author gratefully acknowledges the Department of Science and Technology, Government of India, for funding the research project.

\section{References}

Adinarayana J, Rao KG, Krishna NR, Venkatachalam P, Suri JK (1999) A rule-based soil erosion model for a hilly catchment. Catena 37:309-318

Alatorre LC, Begueria S, Lana-Renault N, Navas A, Garcia-Ruiz JM (2012) Soil erosion and sediment delivery in a mountain catchment under scenarios of land use change using a spatially distributed numerical model. Hydrol Earth Syst Sci $16: 1321-1334$

Al-Taiee TM (2005) Distribution of bed sediment material in the Mosul reservoir. Iraq J Environ Hydrol 12:1-8

Angima SD, Stott DE, O'Neill MK, Ong CK, Weesies G (2003) Soil erosion prediction using RUSLE for central Kenyan highland conditions. Agril Ecosyst Environ 97(1-3):295-308

Araujo JC, Knight DW (2005) Review of the measurement of sediment yield in different scales. Eng Civil 58:257-265

Arekhi S, Rostamizad G (2011) Sediment yield estimating from three micro-watersheds by integrated KW-GIUH and MUSLE models. Adv Environ Biol 5:1346-1358

Arnoldus HMJ (1980) An approximation of the rainfall factor in the universal soil loss equation: assessment of erosion. Wiley, Chichester, pp 127-132

Aronica G, Ferro V (1997) Rainfall erosivity over Calabrian region. Hydrol Sci J 42:35-48

ASCE- American Society of Civil Engineers (1982) Relationships between morphology of small streams and sediment yield. Rep. of Task Committee. J Hydrol Div 108:1328-1365

Auerswald K, Fiener P, Gomez JA, Govers G, Quinton JN, Strauss P et al (2015) Comment on "Rainfall erosivity in Europe" by Panagos. Sci Total Environ 511:849-852

Baskan O, Cebel H, Akgul S, Erpul G (2010) Conditional simulation of USLE/RUSLE soil erodibility factor by geostatistics in a Mediterranean Catchment, Turkey. Environ Earth Sci 60:1179-1187

Bayramin I, Basaran M, Erpul G, Canga MR (2008) Assessing the effects of land use changes on soil sensitivity to erosion in a highland ecosystem of semi-arid Turkey. Environ Monit Assess 140:249-265

Beasley DB, Huggins LF, Monke EJ (1980) A model for watershed planning. Tran ASAE 23:938-944

Bennett JP (1974) Concepts of mathematical modelling of sediment yield. Water Resour Res 10:485-492

Biesemans J, Meirvenne MV, Gabriels D (2000) Extending the RUSLE with the Monte Carlo error propagation technique to predict long-term average off-site sediment accumulation. J Soil Water Conserv 55:35-42

Borland WM (1971) Reservoir sedimentation. Chapter 29 in river mechanics. Water Resour Publ Fort Collins, Colorado State University, 29:1-38

Borland WM, Miller CR (1958) Distribution of sediment in large reservoirs. J Hydrol Div 84:1587.1-1587.10

Boyce RC (1975) Sediment routing with sediment-delivery ratios. In: Present and prospective technology for predicting sediment yields and sources. Proceedings of the sediment-yield workshop, USDA Sedimentation Lab, Oxford, Mississippi, Nov. 28-30, U. S. Dept. of Agril., ARS-S-40:61-65

Breshears DD, Whicker JJ, Johansen MP, Pinder JP (2003) Wind and water erosion and transport in semi-arid shrubland, grassland and forest ecosystems: quantifying dominance of horizontal winddriven transport. Earth Surf Process Landf 28:1189-1209

Brown CB (1943) Discussion of sedimentation in reservoirs. Tran ASCE 69:1493-1500

Browning GM, Norton RA, McCall AG (1948) Investigations in erosion control and the reclamation of eroded land at the Missouri valley loess conservation experiment control Station, Clarinda. Iowa USDA Tech Bull 959:1931-1942

Brune GM (1953) Trap efficiency of reservoirs. Tran Am Geophys Union 34:407-418

Cai C, Ding S, Shi Z, Huang L, Zhang G (2000) Study of applying USLE and geographical information system IDRISI to predict soil erosion in small watershed. J Soil Water Conserv 14:19-24

Capolongo D, Diodato N, Mannaerts CM, Piccarreta M, Strobl RO (2008) Analyzing temporal changes in climate erosivity using a simplified rainfall erosivity model in Basilicata (southern Italy). J Hydrol 356:119-130

Ceylan A, Karabork H, Ekozoglu I (2011) An analysis of bathymetric changes in Altinapa reservoir. Carpath $\mathrm{J}$ Earth Environ Sci 6:15-24

Chang HH (2006) Generalized computer program: Fluvial-12 Mathematical model for erodible channels users manual San Diego. San Diego State University, CA

Chaudhry M, Habib-ur-Rehman M, Akhtar MN, Hashmi HN (2014) Modelling sediment deposition and sediment flushing through reservoirs using 1-D numerical model. Arab J Sci Eng 39:647-658

Chen YH, Lopez JL, Richardson EV (1978) Mathematical modelling of sediment deposition in reservoir. J Hydrol Div 104:1605-1616

Chen CN, Tsai CH, Tsai CT (2006) Simulation of sediment yield from watershed by physiographic soil erosion-deposition model. J Hydrol 327:293-303

Churchill MA (1948) Discussion of analysis and use of reservoir sedimentation data. In: Gottchalk LC (ed) Proc. of Federal Interagency Sedimentation Conf., Denver, Colorado, U.S. of Bureau of Reclamation, pp 139-140

Cook HL (1936) The nature and controlling variables of the water erosion process. Soil Sci Soc Am Proc 1:487-494

Crawford CG (1991) Estimation of suspended-sediment rating curves and mean suspended sediment loads. J Hydrol 129:331-348

Cristofano EA (1953) Area increment method for distributing sediment in a reservoir. U.S. Bureau of Reclamation, Albuquerque, New Mexico

DHI (1999) SEAGIS: soil erosion assessment using GIS. Documentation and user's guide, version 1.48. Danish Hydraulic Institute, Horsholm, Denmark

de Asis AM, Omasa K (2007) Estimation of vegetation parameter for modelling soil erosion using linear spectral mixture analysis of Landsat ETM data. ISPRS J Photogr Remote Sens 62:309-324

De Roo APJ, Wesseling CG, Cremers NHDT, Offermans RJE, Ritsema CJ, Van Oostindie K (1994) LISEM: a new physicallybased hydrological and soil erosion model in a GIS-environment: theory and implementation. Variab Str Erosion Sedim Transp 224:439-448

De Vente J, Poesen J, Arabkhedri M, Verstraeten G (2007) The sediment delivery problem revisited. Prog Phys Geogr 31(2): 155-178

Dendy FE (1974) Sediment trap-efficiency of small reservoirs. Tran ASAE 17:898-988

Dendy FE, Bolton GC (1976) Sediment yield-runoff-drainage area relationships in the U.S. J Soil Water Conserv 32:264-266

Deniz E, Recep E, Isa C (2008) Erosion analysis of sahim creek watershed (NW of Turkey) using GIS based on RUSLE (3d) method. J Appl Sci 8:49-58 
DLWC (1995) Integrated water quantity-quality model, reference manual, DLWC report no. TS94.048. Department of Land and Water Conservation, Parramatta, NSW, Australia

Dhruvnarayana VV, Ram B (1983) Estimation of Runoff from small watershed of Doon valley. J Inst Eng Ag 64:1-4

Donald G, Greet G, Wouter S, Ilse R (2003) Assessment of USLE cover management $C$-factors for 40 crop rotation systems on arable farms in the Kemmelbeek watershed, Belgium. Soil Tillage Res 74:47-53

Driscoll ED (1986) Lognormality of point and nonpoint source pollutant concentrations. In: Proceedings of the stormwater and water quality model users group meeting, Orlando, EPA/600/086/023:157-176

Durigon VL, Carvalho DF, Antunes MAH, Oliveira PTS, Fernandes MM (2014) NDVI time series for monitoring RUSLE cover management factor in a tropical watershed. Int J Remote Sens $35: 441-453$

El-Manadely MS (1991) Simulation of sediment transport in the Aswan High Dam Lake. Ph.D. Dissertation, Irrigation and Hydraulic Dept., Cairo University, Egypt

Elwell HA (1978) Soil loss estimation: compiled works of the Rhodesian multi-disciplinary team on soil loss estimation. Institute of Agricultural Engineers, Salisbury, Zimbabwe

Ewen J, Parkin G, O'connell PE (2000) SHETRAN: a coupled surface/subsurface modelling system for 3D water flow and sediment and solute transport in river basins. J Hydrol Eng $5: 250-258$

Feng X, Wang Y, Chen L, Fu B, Bai G (2010) Modelling soil erosion and its response to land-use change in hilly catchments Chinese Loess Plateau. Geomorp 118:239-248

Fernandez C, Wu JQ, McCool DK, Stockle CO (2003) Estimating water erosion and sediment yield with GIS, RUSLE and SEDD. J Soil Water Conserv 58:128-136

Ferro V, Giordano G, Lovino M (1991) Iso-erosivity and erosion risk map for Sicily. Hydrol Sci J 36:549-564

Ferro V, Porto P, Yu B (1999) A comparative study of rainfall erosivity estimation for Southern Italy and southeastern Australia. Hydrol Sci J 44:3-24

Fistikogli O, Harmancioglu NB (2002) Integration of GIS with USLE in assessment of soil erosion. Water Resour Manag 16:447-467

Flacke W, Auerswald K, Neufang L (1990) Combining a modified universal soil loss equation with a digital terrain model for computing high resolution maps of soil loss resulting from rain wash. Catena 17:383-397

Flaxman EM (1972) Predicting sediment yield in Western U.S. J Hydrol Div 98:2073-2085

FAO (1997) Field measurement of soil erosion and runoff. FAO Soils Bulletin, Food and Agriculture Organization, United Nations, Rome

Foster IDL (2006) Lakes in the sediment delivery system. Soil erosion and sediment redistribution in river catchments: measurement, modelling and management. CAB Int. Wallingford, pp 128-142

Foster GR, Yoder DC, Weesies GA, McCool DK, McGregor KC, Binger RL (2002) RUSLE2 User's guide, USDA-Agricultural Research Service, Washington, pp 1-76

Fu G, Chen S, McCool KD (2006) Modelling the impacts of no-till practice on soil erosion and sediment yield using RUSLE, SEDD and ArcView GIS. Soil Tillage Res 85:38-49

Fukuyama T, Takenaka C, Onda Y (2005) 137Cs loss via soil erosion from a mountainous headwater catchment in Japan. Sci Total Environ 350:238-247

Fuska J, Barek V, Pokryvkova J, Hala P (2014) Comparison of actual and presumed water capacity of fish pond in Lukacovce. J Int Sci Publ Econ Safe 8:409-414

Gabriels D, Ghekiere G, Schiettecatte W, Rottiers I (2003) Assessment of USLE cover-management C-factors for 40 crop rotation systems on arable farms in the Kemmelbeek watershed, Belgium. Soil Tillage Res 74:47-53

Garde RJ, Kothyari UC (1987) Sediment yield estimation. J Irrig Power 44(3): $97-123$

Garg V, Jothiprakash V (2010) Modelling the time variation of reservoir trap efficiency. J Hydrol Eng 15:1001-1015

Gill MA (1979) Sedimentation and useful life of reservoirs. J Hydrol 44:89-95

Graf WH (1984) Hydraulics of sediment transport. McGraw-Hill, New York, Water Resources Publ. Littleton, CO, USA, p 513

Hanley N, Faichney R, Munro A, Shortle JS (1998) Economic and environmental modelling for pollution control in an estuary. J Environ Manag 52:211-225

Hann CT, Barfield BJ, Hayes JC (1994) Design hydrology and sedimentology for small catchments. Academic Press, A div. of Harcourt Brace and Company, New York, p 588

Heinemann HG (1981) A new sediment trap efficiency curve for small reservoirs. Water Resour Bull 17:825-830

Horowitz AJ (2003) An evaluation of sediment rating curves for estimating suspended sediment concentrations for subsequent flux calculations. Hydrol Process 17:3387-3409

Hoyos N (2005) Spatial modelling of soil erosion potential in a tropical watershed of the Colombian Andes. Catena 63:85-108

Hudson NW (1975) The factors determining the extent of soil erosion. Soil conservation and management in the humid tropics. Wiley, New York

IS 5477-Part 2 (1994) Fixing the capacities of reservoirs-methods. Bureau of Indian Standards, New Delhi, India

Jain SK, Goel MK (2002) Assessing the vulnerability to soil erosion of the Ukai Dam catchment using remote sensing and G1S. Hydrol Sci J 47:31-40

Jain MK, Kothyari UC, Raju KGR (2005) GIS based distributed model for soil erosion and rate of sediment outflow from catchments. J Hydrol Eng 131:755-769

Jetten V, de Roo A, Favis-Mortlock D (1999) Evaluation of field-scale and catchment-scale soil erosion models. Catena 37(4):521-541

Johanson RC, Imhoff JC, Davis HH (1980) User manual for the Hydrologic Simulation Program-Fortran (HSPF). U.S. Environmental Protection Agency, Office of Research and Development, Environmental Research Laboratory, Athens, EPA-600/980-105, p 678

Johnson YW (1943) Distribution graphs of suspended-matter concentration. Tran ASCE 108:941-964

Khosla AN (1953) Silting of reservoirs. Central Water and Power Comm. Govt. of Indian Press, Shimla, India, 51, p 203

Kim JB, Saunders P, Finn JT (2005) Rapid assessment of soil erosion in the Rio Lempa Basin, Central America, using the universal soil loss equation and geographic information systems. Environ Manag 36:872-885

Kinnell PIA (2004) Sediment delivery ratios: a misaligned approach to determining sediment delivery from hillslopes. Hydrol Process 18:3191-3194

Kinnell P, Risse L (1998) USLE-M: empirical modelling rainfall erosion through runoff and sediment concentration. Soil Sci Soc Am J 62:1667-1672

Kirkby MJ, Jones RJA, Irvine B, Gobin A, Govers G, Cerdan O, Van Rompaey AJJ, Le Bissonnais Y, Daroussin J, King D, Montanarella L, Grimm M, Vieillefont V, Puigdefabregas J, Boer M, Kosmas C, Yassoglou N, Tsara M, Mantel S, Van Lynden GJ, Huting J (2004) Pan-European soil erosion risk assessment: the PESERA map, version 1 October 2003 Explanation of Special Publication Ispra 2004 No. 73 (S.P.I.04.73), European Soil Bureau Research Rep. No. 16, EUR 21176 and map in ISO B1 format, European Comm. Joint Research Centre, Ispra/Institute for Environment and sustainability. Available from: Office for Official Publ. of the European Communities, Luxembourg 
Kirurhika AM, Arunachalam S, Reddy AK, Suresh SB (2011) Silt sediment analysis for Devarabelekere reservoir using remote sensing and GIS. Int J Earth Sci Eng 4:24-30

Knisel WG (1980) CREAMS: a field scale model for chemicals, runoff and erosion from agricultural management systems. Conservation Research Rep. No. 26, U.S. Dept. of Agriculture

Kosmas C, Gerontidis S, Marathianou M (2001) The effects of tillage displaced soil on soil properties and wheat biomAssess. Soil Tillage Res 58:31-44

Krishnaswamy J, Richter DD, Halpin PN, Hofmockel MS (2001) Spatial patterns of suspended sediment yields in a humid tropical watershed in Costa Rica. Hydrol Process 15:2237-2257

Langland MJ, Hainly RA (1997) Changes in bottom surfaceelevations in three reservoirs on the Lower Susquehanna River, Pennsylvania and Maryland, following the January 1996 floodImplications for nutrient and sediment loads to Chesapeake Bay. U.S. Geological Survey Water-Resources Investigations Rep. 97-4138, Reston, p 34

Laronne JB, Mosley MP (1982) Erosion and sediment yield. Benchmark papers in Geology Hutchinson Ross, Pennsylvania, $63, \mathrm{p} 375$

Lee CT (1997) Methods of soil erosion measurement. J Geogr Sci 23:89-106

Lee JH, Heo JH (2011) Evaluation of estimation methods for rainfall erosivity based on annual precipitation in Korea. J Hydrol 409:30-48

Legesse D, Vallet-Coulomb D, Gasse F (2003) Hydrological response of a catchment to climate and land use changes in tropical Africa: case study South Central Ethiopia. J Hydrol 275:67-85

Li Y, Poesen J (2003) Evaluating gully erosion using 137Cs and $210 \mathrm{~Pb} / 137 \mathrm{Cs}$ ratio in a reservoir catchment. Soil Tillage Res 69:107-115

Lim KJ, Sagong M, Engel BA, Tang Z, Choi J, Kim KS (2005) GIS based sediment assessment tool. Catena 64:61-80

Lin CY, Lin WT, Chou WC (2002) Soil erosion prediction and sediment yield estimation: the Taiwan experience. Soil Tillage Res 68(2):143-152

Littleboy M, Silburn DM, Freebairn DM, Woodruff DR, Hammer GL, Leslie JK (1992) Impact of soil erosion on production in cropping systems. I. Development and validation of a computer simulation model. Aust J Soil Res 30:757-774

Liu BY, Nearing MA, Risse LM (1994) Slope gradient effects on soil loss for steep slopes. Tran ASAE 37:1835-1840

Lu D, Li G, Valladares GS, Batistella M (2004) Mapping soil erosion risk in Rondonia, Brazilian Amazonia: using RUSLE, remote sensing and GIS. Land Degrad Dev 15:499-512

Maetens W, Vanmaercke M, Poesen J, Jankauskas B, Jankauskiene G, Ionita I (2012) Effects of land use on annual runoff and soil loss in Europe and the Mediterranean: a metaanalysis of plot data. Prog Phys Geogr 36(5):597-651

Manoj KJ, Umesh CK (2000) Estimation of soil erosion and sediment yield using GIS. Hydrol Sci J 45:771-786

McCool DK, Brown LC, Foster GR (1987) Revised slope steepness factor for the universal soil loss equation. Trans ASAE 30:1387-1396

Md. Habili J, Heidarpour M (2010) New empirical method for prediction of sediment distribution in reservoirs. J Hydrol Eng $15: 813-821$

Merritt WS, Letche RA, Jakeman AJ (2003) A review of erosion and sediment transport models. Environ Mod Soft 18:761-799

Mikhailova EA, Bryant RB, Schwager SJ, Smith SD (1997) Predicting rainfall erosivity in Honduras. Soil Sci Soc Am J 61:273-279

Millward AA, Mersey JE (1999) Adapting the RUSLE to model soil erosion potential in a mountainous tropical watershed. Catena 38:109-129
Misra RK, Rose CW (1990) Manual for use of program GUEST. Div. of Australian Environmental Studies Rep. Griffith University, Brisbane, Australia, p 4111

Mitasova H, Hofierka J, Zlocha M, Iverson LR (1996) Modelling topographic potential for erosion and deposition using GIS. Int J Geogr Inf Syst 10:629-641

Moldovanu A, Boeriu P, Margaritescu M (2011) Assessment of the sedimentation process in reservoirs using real time acoustic measurements in fixed points. In: Proceedings of COMEFIM'10

Morgan RPC, Quinton JN, Smith RE, Govers G, Poesen JWA, Auerswald K, Chisci G, Torri D, Styczen ME (1998) The European Soil Erosion Model (EUROSEM): a process-based approach for predicting sediment transport from fields and small catchments. Earth Surf Process Landf 23:527-544

Morris GL, Fan J (1998) Reservoir sedimentation handbook. Tata McGraw-Hill Publishing Company, New York

Musgrave GW (1947) The quantitative evaluation of factors in water erosion: a first approximation. J Soil Water Conserv 2:133-138

Nearing MA, Foster GR, Lane LJ, Finkner SC (1989) A process based soil erosion model for USDA-water erosion prediction project technology. Tran ASAE 32:1587-1593

Neil DT, Mazari RK (1993) Sediment yield mapping using small dam sedimentation surveys, Southern Tablelands, New South Wales. Catena 20:13-25

Neitsch SL, Arnold JG, Kiniry JR, Williams JR (2005) Soil and water assessment tool theoretical documentation, version 2005. Texas, USA

O'Loughlin EM (1986) Prediction of surface saturation zones in natural catchments by topographic analysis. Water Resour Res 22:794-804

Oliveira PTS, Rodrigues DBB, Sobrinho TA, Panachuki E, Wendland E (2013a) Use of SRTM data to calculate the $R$ (USLE) topographic factor. Acta Sci Technol 35:507-513

Oliveira PTS, Wendland E, Nearing MA (2013b) Rainfall erosivity in Brazil: a review. Catena 100:139-147

Pacific Southwest Inter Agency Committee (PSIAC) (1968) Rep. of the water management subcommittee on factors affecting sediment yield in the Pacific Southwest area and selection and evaluation of measures for reduction of erosion and sediment yield. Sacramento, California: Pacific Southwest Region Planning Office, U.S. Dept. of the Interior, ASCE. 98, p 10

Panagos P, Ballabio C, Borrelli P, Meusburger K, Klik A, Rousseva S, Tadic MP, Michaelide S, Hrabalikova M, Olsen P, Aalto J, Lakatos M, Rymszewicz A, Dumitrescu A, Begueria S, Alewell C (2015) Rainfall erosivity in Europe. Sci Total Environ 511:801-814

Paringit EC, Nadaoka K (2003) Sediment yield modelling for small agricultural catchments: land-cover parameterization based on remote sensing data analysis. Hydrol Process 17:1845-1866

Parsons AJ, Wainwright J, Brazier RE, Powell DM (2006) Is sediment delivery a fallacy? Earth Surf Process Landf 31:1325-1328

Prosser IP, Young WJ, Rustomji P, Hughes AO, Moran CJ (2001c) A model of river sediment budgets as an element of river health assessment. In: Proceedings of the international congress on modelling and simulation (MODSIM'2001), pp 861-866

Renard KG, Freimund JR (1994) Using monthly precipitation data to estimate the $R$ factor in the revised USLE. J Hydrol 157:287-306

Renard KG, Laursen EM (1975) Dynamic behavior model of ephemeral streams. J Hydrol Div 101:511-526

Renard KG, Foster GR, Weesies GA, McCool DK, Yoder DC (1996) RUSLE user's guide. Soil Water Conserv Soc $\mathrm{p} 173$

Renard KG, Foster GR, Weesies GA, McCool DK, Yoder DC (1997) Predicting soil erosion by water: a guide to conservation planning with the revised universal soil loss equation RUSLE. U.S. Dept. of Agriculture, Agricultural Handbook No. 703, Washington, p 404 
Rendon-Herrero O (1978) Unit sediment graph. Water Resour Res 14:889-901

Renschler CS, Harbor J (2002) Soil erosion assessment tools from point to regional scales: the role of geomorphologists in land management research and implementation. Geomorp 47:189-209

Risse LM, Nearing MA, Nicks AD, Laflen JM (1993) Error assessment in the universal soil loss equation. Soil Sci Soc Am J 57:825-833

Ritchie JC, Walling DE, Peters J (2003) Application of geographic information systems and remote sensing for quantifying patterns of erosion and water quality. Hydrol Process 17(5):885-886

Roose EJ (1980) Approach to the definition of rain erosivity and soil erodibility in West Africa. In: Boodt MD, Gabriels D (eds) Assessment of erosion. Wiley, New York, pp 153-164

Rose CV, Williams JR, Sander GC, Barry DA (1983) A mathematical model of soil erosion and deposition process. I. Theory for a plane element. Soil Sci Soc Am J 47:991-995

Rowan JS, Goodwill P, Greco M (1995) Temporal variability in catchment sediment yield determined from repeated bathymetric surveys: abbystead reservoir, UK. Phys Chem Earth 20:199-206

Schmidt J (1991) A mathematical model to simulate rainfall erosion. Erosion, transport and deposition processes-theories and models. Catena 19:101-109

Schmidt KH, Morche D (2006) Sediment output and effective discharge in two small high mountain catchments in the Bavarian Alps Germany. Geomorp 80:131-145

Schonbrodt S, Saumer P, Behrens T, Seeber C, Scholten T (2010) Assessing the USLE crop and management factor $\mathrm{C}$ for soil erosion modelling in a large, mountainous watershed in Central China. J Earth Sci 21:835-845

Shen HW, Julien PY (1993) Erosion and sediment transport. Handbook of hydrology. McGraw-Hill, New York, pp 121-1261

Smith DD (1941) Interpretation of soil conservation data for field use. Agril Eng 22:173-175

Smith DD, Whitt DM (1948) Estimating soil losses from field areas. Agril Eng 29:394-398

Smith RE, Goodrich DC, Quinton JN (1995) Dynamic, distributed simulation of watershed erosion: the KINEROS2 and EUROSEM models. J Soil Water Conserv 50:517-520

Soares EF, Unny TE, Lennox WC (1982) Conjunctive of deterministic and stochastic models for predicting sediment storage in large reservoirs. J Hydrol 59:83-105

Soil Survey Staff (1997) National characterization data. Soil Survey Lab., National Soil Survey Center, National Resources Conservation Service, Lincoln, NE

Star JL, Estes JE, McGwire KC (1997) Integration of geographic information systems and remote sensing. Cambridge University Press, Cambridge, UK

Stephen EL, Bainbridge ZT, Kuhnert PM, Sherman BS, Henderson B, Dougall C, Cooper M, Brodie JE (2013) Calculating sediment trapping efficiencies for reservoirs in tropical settings: a case study from the Burdekin Falls Dam, NE Australia. Water Resour Res 49:1017-1029

Subramanya K (2008) Engineering hydrology. Tata McGraw-Hill Publishing Company, New York

Sun H, Cornish PS, Daniell TM (2002) Contour-based digital elevation modelling of watershed erosion and sedimentation: erosion and sedimentation estimation tool (EROSET). Water Resour Res 38:1-10

Suresh R (2000) Soil and water conservation engineering. Standard Publishers Distributors, New Delhi

SWCS (Soil and Water Conservation Society) (1995) Agriculture and the environment: listening to the grassroots. Ankeny, Iowa

Takken I, Beuselinck L, Nachtergaele J, Govers G, Poesen J, Degraer G (1999) Spatial evaluation of a physically-based distributed erosion model (LISEM). Catena 37:431-447
Torri D, Borselli L, Guzzetti F, Calzolari C, Bazzoffi P, Ungaro F, Bartolini D, Salvador MP (2006) Soil erosion in Italy: an overview. Soil erosion in Europe, Wiley, Chichester, UK pp 245-261

U.S. Army Corps of Engineers (1993) HEC-6 scour and deposition in rivers and reservoirs user's manual. Hydrologic Engg Center, Davis, CA

U.S. Bureau of Reclamation (1987) The design of small dams: a water resources technical publication. U.S. Govt. Printing Office, Washington, D.C

U.S. Department of Agriculture, Agricultural Research Service, National Sediment Laboratory (USDA-ARS-NSL) (2003) RUSLE1.06c and RUSLE

USEPA (U.S. Environmental Protection Agency) (1994) SWRRBWQ: window's interface users guide. U.S. Environmental Protection Agency, Washington, DC

Vaezi AR, Sadeghi SHR, Bahrami HA, Mahdian MH (2008) Modelling the USLE $K$ factor or calcareous soils in northwestern Iran. Geomorp 97:414-423

Van der Knijff JM, Jones RJA, Montanarella L (1999) Soil erosion risk assessment in Italy. European Soil Bureau, Joint Research Center of the European Comm p 52

Van der Knijff JM, Jones RJA, Montanarella L (2000) Soil erosion risk assessment in Europe. European Soil Bureau, Joint Research Center of the European Comm p 34

Van Doren CA, Bartelli LJ (1956) A method of forecasting soil losses. Agril Eng 37:335-341

Van Leeuwen WJD, Sammons G (2004) Vegetation dynamics and soil erosion modelling using remotely sensed data (MODIS) and GIS. In: 10th Biennial USDA forest service remote sensing applications conference on, U.S., Dept. of Agriculture Forest Service Remote Sensing Applications Centre, Salt Lake City

Van Rijn LC (2006) Manual sediment transport measurements. Aqua Publication, Blokzijl

Van RD, Maichle RW, Hickey RJ (2004) Computing the LS factor for the revised universal soil loss equation through array-based slope processing of digital elevation data using a $\mathrm{C}++$ executable. Comput Geosci 30:1043-1053

Vanoni VA (1975) Sedimentation engineering. Manuals and reports on engineering practice. American Society of Civil Engineers, New York, 54, p 745

Veihe A, Rey J, Quinton JN, Strauss P, Sancho FM, Somarriba M (2001) Modelling of event-based soil erosion in Costa Rica, Nicaragua and Mexico: evaluation of the EUROSEM model. Catena 44:187-203

Verstraeten G, Poesen J (1999) The nature of small-scale flooding, muddy floods and retention pond sedimentation in central Belgium. Geomorp 29:275-292

Verstraeten G, Poesen J (2000) Estimating trap efficiency of small reservoirs and ponds: methods and implications for the assessment of sediment yield. Prog Phys Geogr 24:219-251

Verstraeten G, Poesen J (2001) Modelling the long-term sediment trap efficiency of small ponds. Hydrol Process 15:2797-2819

Verstraeten G, Poesen J (2002) Using sediment deposits in small ponds to quantify sediment yield from small catchments: possibilities and limitations. Earth Surf Process Landf 27:1425-1439

Vertessey RA, Watson FGR, Rahman JM, Seaton SP, Chiew FH, Scanlon PJ, Marston FM, Lymbuner L, Jeanelle S, Verbunt M (2001) New software to aid water quality management in the catchments and waterways of the south-east Queensland region. In: Proceedings of the 3rd Australian STREAM MANAGEMENT CONF. Brisbane, 2, pp 611-616

Villegas COE, Schnoor JL (2009) Comparison of long-term observed sediment trap efficiency with empirical equations for Coralville Reservoir, Iowa. J Environ Eng 135:518-525 
Viney NR, Sivapalan M (1999) A conceptual model of sediment transport: application to the Avon River Basin in Western Australia. Hydrol Process 13:727-743

Vrieling A (2006) Satellite remote sensing for water erosion assessment: a review. Catena 65:2-18

Walling DE (1983) The sediment delivery problem. J Hydrol 65:209-237

Wang G, Gertner G, Liu X, Anderson A (2001) Uncertainty assessment of soil erodibility factor for revised universal soil loss equation. Catena 46:1-14

Wang G, Wente S, Gertner GZ, Anderson A (2002) Improvement in mapping vegetation cover factor for the universal soil loss equation by geostatistical methods with Landsat Thematic Mapper images. Int J Remote Sens 23:3649-3667

Ward AD, Haan CT, Barfield BJ (1977) The performance of sediment detention structures. In: Proceedings of the international symposium on urban hydrology hydraulics and sediment control, University of Kentucky, pp 58-68

WCD (World Commission on Dams) (2000) Dams and development: a new framework for decision-making. Earthscan Publ. Ltd., London, p 356

Williams JR (1975) Sediment routing for agricultural watersheds. Water Resour Bull 11:965-974

Williams JR (1978) A sediment graph model based on an instantaneous unit sediment graph. Water Resour Res 14:659-664

Williams JR, Berndt HD (1977) Sediment yield prediction based on watershed hydrology. Tran ASAE 20:1100-1104

Williams JR, Jones CA, Dyke PT (1984) A modelling approach determining the relationship between erosion and soil productivity. Tran ASAE 27:129-144

Wilson BN, Barfield BJ (1984) A sediment detention pond model using CSTRS mixing theory. Tran ASAE 27:1339-1344

Wilson BN, Barfield BJ (1985) Modelling sediment detention ponds using reactor theory and advection- diffusion concepts. Water Resour Res 21:523-532

Wischmeier WH (1959) A rainfall erosion index for a universal soilloss equation. Soil Sci Soc Am Proc 23:246-249

Wischmeier WH, Mannering JR (1969) Relation of soil properties to its erodibility. Soil Sci Soc Am Proc 33:131-137

Wischmeier WH, Smith DD (1978) Predicting rainfall erosion losses: a guide to conservation planning. USDA Agriculture Handbook No. 537, US Govt. Printing Office, Washington, DC
Wischmeir WH (1960) Erosion rates and contributing factors in semiarid regions. Int. Seminar on Water and Soil Utilization, Brookings, South Dakota

Woolhiser DA, Smith RE, Goodrich DC (1990) KINEROS, a kinematic runoff and erosion model: documentation and user manual U.S. Dept. of Agriculture, Agricultural Research Service, ARS-77, p 130

Yang CT, Simoes FJM (2002) User's manual for GSTARS3 (Generalized Sediment Transport Model for Alluvial River Simulation version 3.0). U.S. Bureau of Reclamation, Technical Service Center, Denver, Colorado

Yang MY, Tian JL, Liu PL (2006) Investigating the spatial distribution of soil erosion and deposition in a small catchment on the Loess Plateau of China, using 137Cs. Soil Tillage Res 87:186-193

Yitayew M, Pokrzywka SJ, Renard KG (1999) Using GIS for facilitating erosion estimation. Appl Eng Agril 15:295-301

Young RA, Onstad CA, Bosch DD, Andersen WP (1989) AGNPS: a nonpoint-source pollution model for evaluating agricultural watersheds. J Soil Water Conserv 44:168-173

Yu B (1999) A comparison of the R-factor in the universal soil loss equation and revised universal soil loss equation. Tran ASAE 42(6): 1615-1620

Yu B, Rosewell CJ (1996) Rainfall erosivity estimation using daily rainfall amounts for South Australia. Aust J Soil Res 34:721-733

Yu B, Hashim GM, Eusof Z (2001) Estimating the $R$-factor with limited rainfall data: a case study from Peninsular Malaysia. J Soil Water Conserv 56:101-105

Zhang XB, Walling DE, Yang Q (2006) 137Cs budget during the period of 1960 s in a small drainage basin on the Loess Plateau of China. J Environ Radio 86:78-91

Zhang ZG, Fan BE, Bai WJ, Jiao JY (2007) Soil anti-erodibility of plant communities on the removal lands in hilly-gully region of the Loess Plateau. Sci Soil Water Conserv 5:7-13

Zhang KL, Shu AP, Xu XL, Yang QK, Yu B (2008) Soil erodibility and its estimation for agricultural soils in China. J Arid Environ 72:1002-1011

Zingg AV (1940) Degree and height of land slope as it affects soil loss in runoff. Agril Eng 21:59-64 